\title{
Obtaining Veterinary Preparations from Aspen Bark and the Study of their Therapeutic and Prophylactic Properties in Experimental Escherichiosis of Animals
}

\author{
Svetlana A. Kuznetsova ${ }^{\star a, b}$, Galina P. Skvortsova ${ }^{a}$, \\ Anastasya A. Moroz ${ }^{\mathfrak{c}}$, Irina V. Korolkova ${ }^{a}$, \\ Svetlana A. Schislenko ${ }^{\mathfrak{c}}$, Vladimir A. Levdansky ${ }^{\mathrm{a}}$, \\ Boris N. Kuznetsov ${ }^{\mathrm{a}, \mathrm{b}}$ and Nikolai V. Chesnokov ${ }^{\mathrm{a}}$ \\ anstitute of Chemistry and Chemical Technology SB RAS \\ FRC "Krasnoyarsk Scientific Center SB RAS" \\ 50/24 Akademgorodok, Krasnoyarsk, 660036, Russia \\ ${ }^{b}$ Siberian Federal University \\ 79 Svobodny, Krasnoyarsk, 660041,Russia \\ ${ }^{c}$ Krasnoyarsk State Agrarian University \\ 90 Mira, Krasnoyarsk, 660049, Russia
}

Received 21.07.2018, received in revised form 18.09.2018, accepted 11.11.2018

It was found that the preparations for the prevention and treatment of the escherichiosis of animals, obtained from aspen bark have the good sorption properties in relation to gelatin and methylene blue. It was experimentally established that the all obtained preparations can be used for the prevention and treatment of the escherichiosis of animals.

Good therapeutic and prophylactic properties have been proven for the sample of initial aspen bark at a dose of $0.15-0.20 \mathrm{~g} / \mathrm{kg}$ and for the sample of aspen bark with supported arabinogalactan at a dose of $0.15 \mathrm{~g} / \mathrm{kg}$. The average level of therapeutic efficacy was established for the sample of extracted aspen bark at a dose of $0.15-0.20 \mathrm{~g} / \mathrm{kg}$. The highest efficacy in the treatment and prevention of acute experimental escherichiosis was established for the sample of "aspen fat" extracted by hexane from aspen bark, when administrated at optimal doses of 0/10-0.15 g/kg.

Keywords: aspen bark, preparation, sorption, gelatin, methylene blue, escherichiosis, intestinal infections.

(c) Siberian Federal University. All rights reserved

* Corresponding author E-mail address: ksa@icct.ru 
Citation: Kuznetsova S.A., Skvortsova G.P., Moroz A.A., Korolkova I.V., Schislenko S.A., Levdansky V.A., Kuznetsov B.N., Chesnokov N.V. Obtaining veterinary preparations from aspen bark and the study of their therapeutic and prophylactic properties in experimental escherichiosis of animals, J. Sib. Fed. Univ. Chem., 2018, 11(4), 604-615. DOI: 10.17516/19982836-0103.

\title{
Получение ветеринарных препаратов из коры осины и изучение их лечебно-профилактических свойств при экспериментальном эшерихиозе животных
}

\author{
С.А. Кузнецова ${ }^{a, \tilde{\sigma}}$, Г.П. Скворцова ${ }^{a}$, \\ А.А. Мороз ${ }^{\text {, }}$ И.В. Королькова ${ }^{\mathrm{a}}$, С.А. Счисленко \\ В.А. Левданский ${ }^{a}$, Б.Н. Кузнецов ${ }^{\text {a, }}$, Н.В. Чесноков ${ }^{a}$ \\ ${ }^{a}$ Институт химии и химической технологии СО РАН \\ ФИЦ «Красноярский научный центр СО РАН» \\ Россия, 660036, Красноярск, Академгородок, 50/24 \\ ${ }^{6}$ Сибирский федеральный университет \\ Россия, 660041, Красноярск, пр. Свободныий, 79 \\ ${ }^{8}$ Красноярский государственный аграрный университет \\ Россия, 660049, Красноярск, пр. Мира, 90
}

Показано, что полученные из коры осины препараты для профилактики и лечения эмерихиоза животных имеют хорошие сорбиионные свойства в отномении желатина и метиленового синего. Экспериментально установлено, что все полученные препараты можно использовать для лечения и профилактики эмерихиоза животных. Хорошими терапевтическими и профилактическими свойствами обладает образеи исходной коры осины при введении 0.15-0.2 г/кг и образеи из коры осины с нанесенным арабиногалактаном при введении 0.15 г/кг. Средняя терапевтическая эффективность установлена для образиа из проэкстрагированной коры осины при введении препарата в дозе $0.15-0.2$ г/кг.

Наиболее высокая эффективность в лечении и профилактике острого экспериментального эмерихиоза установлена для препарата на основе «осинового жира», экстрагированного гексаном из коры осины при оптимальных дозах 0,1-0,15 мл/кг.

Ключевые слова: кора осины, препараты, сорбчия, желатин, метиленовый синий, эщерихиоз, кимечные инфекиии.

Осина является одной из наиболее распространенных лиственных пород деревьев в России. При переработке древесины осины отходы коры достигают примерно 15 \%. Кора осины служит ценным сырьем для получения липидного концентрата, богатого линолевой, линоленовой и арахидоновой (витамин F) ненасыщенными жирными кислотами, необходимыми для жизнедеятельности организма [1-8].

$$
-605-
$$


На основе ненасыщенных жирных кислот ученые разрабатывают биологически активные добавки для лечения кардиологических больных, доказаны их антибактериальные свойства [9, 10]. Экстрактивные вещества коры осины можно рассматривать как витаминный концентрат, поскольку помимо непредельных жирных кислот, в них содержатся стерины, витамин Е, фосфатиды, хлорофилл и бета-каротин.

В последние годы ведутся исследования по использованию экстрактов из коры осины для лечения заболеваний желудка, поскольку они обладают противовоспалительными и противоопухолевыми свойствами. Противовоспалительные свойства экстрактов из коры осины обеспечивают простые фенолы, в частности производные салицилового спирта $[11,12]$. Преобладание в коре осины ненасыщенных жирных кислот С18, в том числе линоленовой кислоты, наличие хлорофилла, бета-каротина, альфа-токоферола (витамин Е), фосфатидов и непредельных стеринов (бета-фитостерина) позволяет считать их биоактивными препаратами $[8,11,12]$.

Химический состав основных компонентов коры осины зависит от многих факторов (возраста дерева, сезона рубки, длительности хранения и т.п.). Поэтому приведенные в литературе данные о содержании экстрактивных веществ в коре осины значительно отличаются друг от друга. Изучение химического состава отходов осиновой коры, собранной в окрестностях г. Красноярска, показало, что в коре осины содержится 11,5 \% веществ, извлекаемых диэтиловым эфиром, 16,6 \% трудногидролизуемых полисахаридов, 26,6 \% легкогидролизуемых полисахаридов, 30,1 \% лигнина, 11,7 \% целлюлозы, зольность составляет 3,3 \%. Для выделения экстрактивных веществ из коры осины и разделения их на узкие фракции в ИХХТ СО РАН применяли последовательную экстракцию серией растворителей с возрастающей полярностью, в качестве которых использовали гексан, бензол, диэтиловый эфир, изопропанол, ацетон, воду, 0.1 н водный раствор КОН $[1,13]$.

Суммарный выход экстрактивных веществ достигал 36,8 \%. После частичной отгонки растворителя и охлаждения из гексанового экстракта выход твердого остатка составил около $1 \%$, а выход маслообразной фракции - 7 \%. Твердая фракция гексанового экстракта содержит в основном насыщенные кислоты состава $\mathrm{C}_{16}-\mathrm{C}_{18}$, в то время как маслообразная фракция экстракта имеет наряду с насыщенными еще и непредельные кислоты. Содержание жирных кислот в маслообразной фракции, выделенной из гексанового экстракта осиновой коры, определяли методом ГЖХ. Липидные соединения переводили в метиловые эфиры и анализировали с использованием хроматографа ЛХМ - 7А с пламенно-ионизационным детектором.

Связанные и свободные жирные кислоты составляют основную массу маслообразной фракции гексанового экстракта. Линоленовая и линолевая кислоты, суммарное содержание которых в гексановом экстракте может превышать $60 \%$, относятся к незаменимым и обладают F-витаминной активностью, поэтому гексановый экстракт называют F-витаминный комплекс или «осиновый жир». После выделения из гексанового экстракта твердой фракции суммарное количество линолевой и линоленовой кислот в жидком компоненте возрастает до $70 \%$.

Установлено, что до 90 \% всех жирных кислот в «осиновом жире» находится в связанном состоянии в виде глицеридов, фосфолипидов и т.п. Биологическая ценность «осинового жира» значительно возрастает с увеличением доли непредельных жирных кислот, находящихся в сво- 
бодном состоянии $[3,7]$. Накопленные исследования ученых свидетельствуют о том, что кора осины может являться лекарственным сырьем для использования в ветеринарии.

Для лечения генерализованных кишечных инфекций сельскохозяйственных животных применяют в основном антибиотики, сульфаниламиды, препараты нитрофуранового ряда, а также специфические сыворотки, арсенал которых ограничен.

Однако используемые методы лечения в большинстве своем малоэффективны, дорогостоящи и экологически опасны в связи с образованием антибиотикоустойчивых штаммов и снижением общей реактивности организма [14].

Ранее нами были представлены результаты успешного лечения данной группы заболеваний энтеросорбентами на основе коры березы [15-17] и коры лиственницы [18]. В продолжение этих исследований в данной работе изучена возможность применения препаратов из коры осины для лечения и профилактики генерализованных кишечных инфекций сельскохозяйственных животных.

\section{Экспериментальная химическая часть}

Исходным сырьем для получения твердых препаратов из коры осины и жидкого осинового жира служила кора осины (Populus tremula L.). Кору осины измельчали на роторной мельнице PM 120, фракционировали до фракций 1-2 и менее 0.5 мм и сушили при температуре $50-60{ }^{\circ} \mathrm{C}$ до воздушно-сухого состояния. Влажность исходной коры осины составляла 5,8土0,2\%.

Для экспериментов было подготовлено пять образцов препаратов.

Препарат № 1 представлял собой твердый остаток после экстракции гексаном коры осины фракции 1-2 мм по методике, описанной в работах $[16,19]$.

Препарат № 2 был приготовлен путем измельчения исходной коры осины до фракции 0,5 мм.

Препарат № 3 был получен измельчением исходной коры осины до фракции 0,5 мм. В отличие от препарата № 2 для усиления фармакологической активности кора осины была пропитана раствором биологически активного арабиногалактана (АГ), выделенного из древесины лиственницы. На 5 частей измельченной коры осины использовали 1 часть АГ. Содержание АГ по отношению к коре в данном препарате составляло $20 \%$.

Препарат № 4 представлял собой жидкий экстракт в виде маслообразной фракции «осинового жира» или $\mathrm{F}$ витаминного комплекса после экстракции коры осины фракции 1-2 мм гексаном и отделения твердой фракции (препарат № 1).

Определение сорбционной активности препаратов из коры осины проводили по маркерным веществам с разной молекулярной массой. Концентрация маркеров в модельных растворах составляла 0,15 \% для метиленового синего (MC) и 0,60 \% для желатина. Сорбцию МС проводили по методике, описанной в работе [19], а желатина - в соответствии с методикой [20].

ИК-спектры энтеросорбента до и после сорбции маркерных веществ были получены на ИК-Фурье-спектрометре IRTraser-100 (Shimadzu, Япония) в области 4000-400 см-1. Образцы для получения ИК-спектров готовили в виде таблеток в матрице бромистого калия при одинаковых условиях. Полученная спектральная информация была обработана с помощью пакета программ LabSolution IR.

$$
-607-
$$


Электронные микрофотографии получены на растровом электронном микроскопе ТМ1000 HITACHI (Япония).

\section{Экспериментальная биологическая часть}

Изучение лечебно-профилактических свойств препаратов из коры осины было проведено на модели генерализованной кишечной инфекции на белых мышах на базе Красноярского государственного аграрного университета.

Были сформированы 4 опытных и 1 контрольная группы животных по 5 голов в каждой группе, средняя масса одной мыши составляла примерно 18 г. Заражение 18-24-часовой агаровой культурой микроорганизмов E.coli серотипа O 138 К 99 проводили внутрибрюшинно в объем 0,2 мл в дозе 500 млн микробных тел в 1 мл. Все животные получали стандартный корм. При изучении профилактического действия энтеросорбента препарат вводили в течение 3 суток до момента заражения культурой E.coli, а для изучения лечебных свойств энтеросорбента - с момента появления первых признаков клинической симптоматики и до полного выздоровления животных. Для установления минимально эффективной дозы препарата каждая опытная группа животных была поделена на 3 подгруппы, получающие препараты из коры осины в дозировке $0,1,0,15$ и 0,2 г на 1 кг массы животного.

В ходе экспериментов оценивали следующие показатели: продолжительность проявления клинических признаков; тяжесть течения заболевания; сохранность лабораторных животных; процент заболеваемости; процент падежа, показатель бактериальной обсемененности кишечника тестовой культурой E.coli. Длительность наблюдения за животными в опытной и контрольной группах составила от 3 до 5 сут.

Количественный показатель бактериальной обсемененности кишечника тестовой культурой E.coli cеротипа O 138 К 99 в 1 г пищеварительного химуса тонкого отдела кишечника изучали по методике, описанной в работе [21]. В случае падежа животных проводили бактериологический анализ содержимого химуса тонкого кишечника анатомо-патологического материала. Отбор материала для бактериологического анализа осуществляли согласно методическим рекомендациям по бактериологической диагностике колибактериоза (эшерихиоза) животных [22].

\section{Результаты и обсуждение}

\section{Изучение сорбционной активности препаратов из коры осины}

Метиленовый синий моделирует класс низкомолекулярных токсикантов и способен адсорбироваться на поверхности мезопор сорбента, размер которых составляет до 2 и от 2-50 нм. Желатин моделирует сорбцию патологических агентов белковой природы (микроорганизмы и их токсины), «молекулы средней массы» и биоактивные кишечные полипептиды эндогенного происхождения и способен адсорбироваться на поверхности макропор сорбента, размер которых более 50 нм.

Данные сорбционной активности препаратов из коры осины по метиленовому синему и по желатину представлены в табл. 1.

Как и следовало ожидать, наибольшей сорбционной активностью по метиленовому синему и желатину обладает препарат из коры осины фракции 1-2 мм после экстракции гексаном и

$$
-608-
$$


Таблица 1. Сорбционная активность препаратов из коры осины

Table 1. Sorption activity of preparations from aspen bark

\begin{tabular}{|c|l|c|c|}
\hline \multicolumn{2}{|c|}{ Препарат } & \multicolumn{2}{c|}{ Сорбционная активность } \\
\hline № & \multicolumn{1}{|c|}{ Название } & по метиленовому синему, мг/г & по желатину, мг/г \\
\hline 1 & Сорбент из коры осины & $154,7 \pm 5,2$ & $168,8 \pm 5,2$ \\
\hline 2 & Исходная кора осины фр. $<0,5$ мм & $76,3 \pm 3,1$ & $133,2 \pm 4,3$ \\
\hline 3 & $\begin{array}{l}\text { Кора осины фр. }<0,5 \text { мм с } \\
\text { нанесенным АГ }\end{array}$ & $63,2 \pm 2,2$ & $110,9 \pm 2,8$ \\
\hline
\end{tabular}

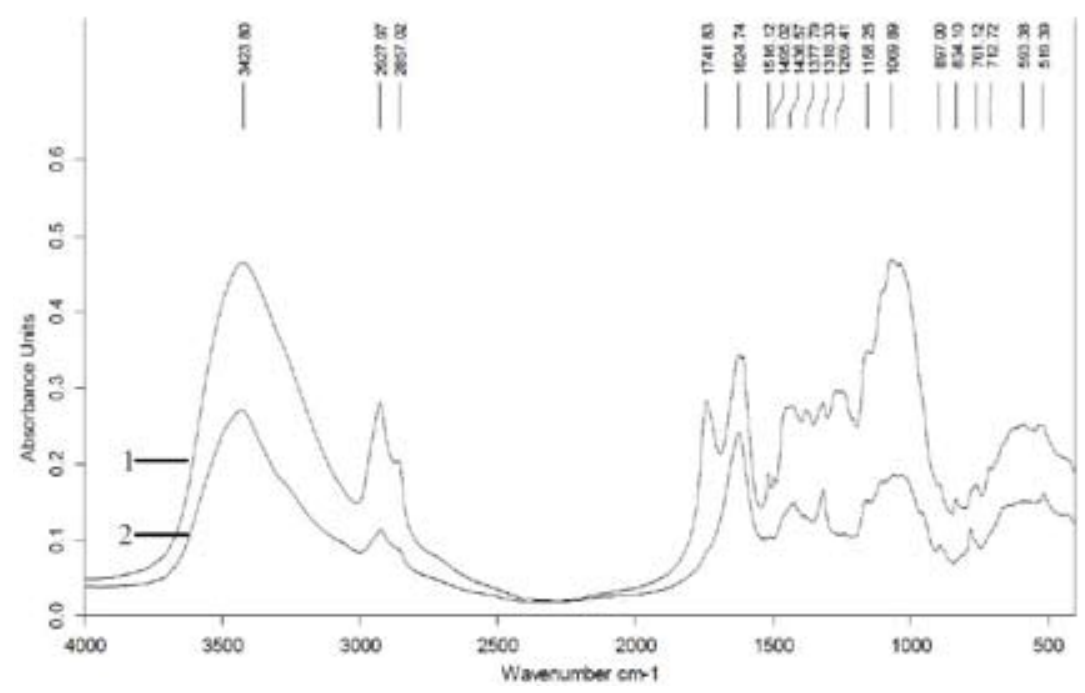

Рис. 1. Кривая 1 - ИК-спектр коры осины фракции менее 0,5 мм (препарат № 2), кривая 2 - ИК-спектр сорбента из коры осины (препарат № 1)

Fig. 1. Curve 1 - IR spectrum of aspen bark fraction less than $0.5 \mathrm{~mm}$ (equipment No. 2), curve 2 - IR spectrum of sorbent from aspen bark (preparation No. 1)

обработки 1,5\%-ным раствором $\mathrm{NaOH}$. Удаление экстрактивных веществ, находящихся в порах коры осины, способствует формированию развитой пористой структуры. Препараты из исходной коры осины фракции менее 0,5 мм и коры осины с нанесенным АГ имеют сорбционную активность в отношении метиленового синего и желатина ниже, чем у препарата 1 , но на уровне сорбентов из луба березы [16].

Сравнительный анализ ИК-спектров коры осины фракции менее 0,5 мм (рис. 1, кривая 1) и сорбента из коры осины (рис. 1, кривая 2) показывает уменьшение интенсивности всех полос поглощения, а также удаление полосы валентных колебаний $\mathrm{C}=\mathrm{O}$-групп при $1741 \mathrm{~cm}^{-1}$ вследствие удаления гексаном жирных кислот, составляющих основную часть жидкого экстракта в виде маслообразной фракции «осинового жира» (препарат № 4).

Наличие арабиногалактана в препарате № 3 подтверждено методом ИК-спектроскопии (рис. 2) и растровой электронной микроскопии (рис. 3).

Из сравнения спектров, приведенных на рис. 2, видно, что в ИК-спектре препарата № 3 (кривая 2) по сравнению с образцом 2 (кривая 1) наблюдается увеличение интенсивностей полос

$$
-609-
$$




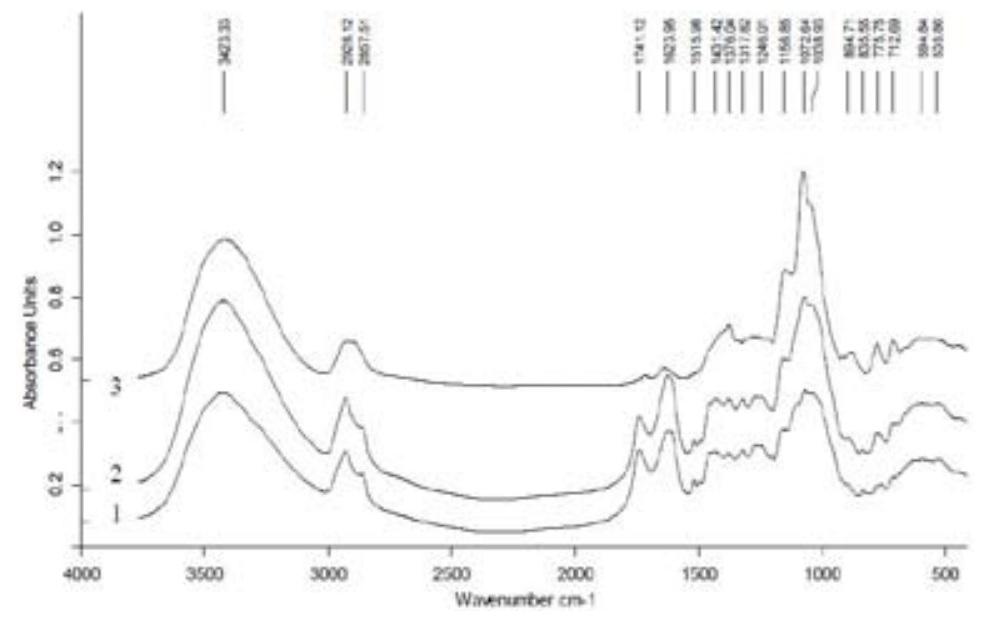

Рис. 2. Кривая 1 - ИК-спектр коры осины фракции менее 0,5 мм (образец 2), кривая 2 - ИК-спектр коры осины фракции менее 0,5 мм с 20 \% АГ (образец 3), кривая 3 - ИК- спектр арабиногалактана

Fig. 2. Curve 1 - IR spectrum of aspen bark fraction less than $0.5 \mathrm{~mm}$ (sample 2), curve 2 - IR spectrum of aspen bark fraction less than $0.5 \mathrm{~mm}$ with $20 \% \mathrm{AH}$ (sample 3), curve 3 - IR spectrum arabinogalactan

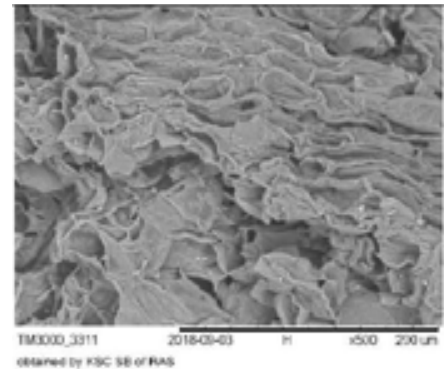

A

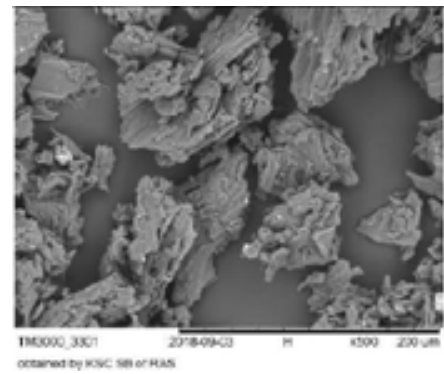

Б

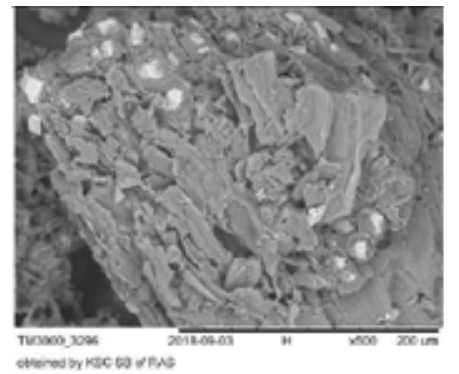

B

Рис. 3. РЭМ изображения препаратов из коры осины (увеличение 500 раз): А - кора осины (фр. 1-2 мм) после экстракции гексаном и обработки щелочью - № 1; Б - исходная кора осины (фр. менее 0,5 мм) № 2; В - исходная кора осины (фр. менее 0,5 мм с нанесенным 20 \% АГ) - № 3.

Fig. 3. SEM images of preparations from aspen bark (magnification 500 times): A - aspen bark (FR. 1-2 mm), after extraction with hexane and treatment with alkali - № 1; Б - initial aspen bark (FR less than 0.5 mm) - № 2; B - initial aspen bark (Fr. Less than $0.5 \mathrm{~mm}$ with deposited $20 \% \mathrm{AH}$ ) - № 3

в области 2800-3000 см-1 (валентные колебания гидроксильных групп, связанных водородными связями), 2960-2750 см-1 (валентные колебания алифатических $\mathrm{CH}_{2}$ и $\mathrm{CH}_{3}$ групп) и 1200-910 см-1 (валентные колебания С-О-групп). Этот факт, на наш взгляд, свидетельствует о наличии арабиногалактана (кривая 3) в составе образца 3. При этом сдвига п.п. в ИК-спектре препарата № 3 не происходит, что свидетельствует об отсутствии химического взаимодействия между корой осины и арабинагалактаном.

Наличие арабиногалактана в препарате 3 подтверждено также методом растровой электронной микроскопии (рис. 3).

В препарате № 3 из исходной коры осины фр. менее 0,5 мм с нанесенным 20 \% АГ наблюдаются множественные вкрапления частиц арабиногалактана в поры коры осины (рис. $3 B$ ). 
Изучение возможности использования препаратов из коры осины

для лечения и профилактики

генерализованных кишечных инфекичий животных

Результаты изучения терапевтической эффективности при лечении острого эшерихиоза препаратов из коры осины на лабораторных мышах представлены в табл. 2.

Все препараты из коры осины в предложенных дозировках оказывали лечебное действие при лечении экспериментального острого эшерихиоза у животных.

Из них наибольшую терапевтическую активностью показал F-витаминный комплекс, или «осиновый жир», при введении препарата в дозе 0.1-0.2 мл/кг живой массы. Исходная кора осины фракции менее 0,5 мм (группа 2) и исходная кора осины с нанесенным 20 \% АГ (группа 3) показали хорошие терапевтические свойства при введении препарата в дозе 0.15 и 0.2 г/кг. В этих опытных группах животных сохранность составила соответственно 100 и 80 \%, срок лечения - 1-2 дня, при этом наблюдалось ускоренное устранение клинических симптомов заболевания, отсутствие нарушения аппетита и активности животных с незначительным проявлением жажды.

Среднюю терапевтическую эффективность показал препарат из проэкстрагированной коры осины при введении препарата в дозе 0.15 и 0.2 г/кг. В этих группах сохранность составила 60 \%, при этом у животных наблюдались признаки эндогенной интоксикации, связанные с повышением жажды, угнетенности и пониженной реакцией на раздражители.

В контрольной группе животных их падеж составил 100 \%.

Таблица 2. Результаты по лечению препаратами из коры осины острого экспериментального эшерихиоза у мышей

Table 2. Results of treatment with preparations from aspen bark acute experimental escherichiosis in mice

\begin{tabular}{|c|c|c|c|c|}
\hline $\begin{array}{l}\text { Опытные группы } \\
\text { линейных мышей }\end{array}$ & $\begin{array}{c}\text { Доза, } \\
\text { г (мл) / кг }\end{array}$ & $\begin{array}{c}\text { Продолжи } \\
\text { тельность } \\
\text { лечения, сут }\end{array}$ & $\begin{array}{c}\text { Тяжесть } \\
\text { течения } \\
\text { заболевания }\end{array}$ & Сохранность, \% \\
\hline \multirow{3}{*}{$\begin{array}{l}\text { 1-я группа } \\
\text { Сорбент из коры осины }\end{array}$} & 0,1 & 4 & средняя & 40 \\
\hline & 0,15 & 3 & средняя & 60 \\
\hline & 0,2 & 3 & средняя & 60 \\
\hline \multirow{3}{*}{$\begin{array}{l}\text { 2-я группа } \\
\text { Исходная кора осины } \\
\phi р .<0,5 \text { мм }\end{array}$} & 0,1 & 2 & средняя & 60 \\
\hline & 0,15 & 1 & низкая & 80 \\
\hline & 0,2 & 1 & низкая & 80 \\
\hline \multirow{3}{*}{$\begin{array}{l}\text { 3-я группа } \\
\text { Кора осины фр. }<0,5 \text { мм с } \\
\text { нанесенным АГ }\end{array}$} & 0,1 & 3 & средняя & 60 \\
\hline & 0,15 & 2 & низкая & 80 \\
\hline & 0,2 & 1 & низкая & 80 \\
\hline \multirow{3}{*}{$\begin{array}{l}\text { 4-я группа } \\
\text { F витаминный комплекс или } \\
\text { «осиновый жир» }\end{array}$} & 0,1 & 1 & низкая & 100 \\
\hline & 0,15 & 1 & низкая & 100 \\
\hline & 0,2 & 1 & низкая & 100 \\
\hline $\begin{array}{l}\text { 5-я группа } \\
\text { Контроль }\end{array}$ & & 5 & тяжелая & 0 \\
\hline
\end{tabular}


Всех павших животных опытных и контрольной групп подвергали патологоанатомическому вскрытию с обязательным высевом биоматериала из внутренних органов для микробиологического исследования.

Во всех опытных группах с высокими показателями сохранности, благодаря хорошим сорбционным свойствам по отношению к бактериальным токсинам введенной культуры микроорганизмов, не было обнаружено признаков токсической нагрузки на организм (отсутствие пролиферации брыжеечных лимфатических узлов, кровоизлияний и дистрофии печени).

В опытных группах со средней сохранностью по результатам патологоанатомического вскрытия установлено наличие единичных диапедезных кровоизлияний на серозных и слизистых покровах брюшной полости, что свидетельствует о незначительном влиянии бактериальных токсинов на органы и ткани желудочно-кишечного тракта.

В контрольной группе животных при вскрытии установлено интенсивное воздействие токсинов кишечной палочки на систему желудочно-кишечного тракта организма, проявившуюся во множественных диапедезных и точечных кровоизлияниях серозных и слизистых покровов брюшной полости, дистрофии тканей печени, пролиферацией сосудов и венозным застоем в большом круге кровообращения.

В табл. 3 представлены данные по изучению возможности использования препаратов из коры осины для профилактики генерализованных кишечных инфекций животных.

Из данных табл. 3 видно, что полученные препараты можно использовать для профилактики генерализованных кишечных инфекций.

Таблица 3. Использование препаратов из коры осины для профилактики генерализованных кишечных инфекций животных

Table 3. The use of drugs from aspen bark for prevention generalized intestinal infections of animals

\begin{tabular}{|c|c|c|c|c|}
\hline $\begin{array}{l}\text { Опытные группы } \\
\text { линейных мышей }\end{array}$ & $\begin{array}{c}\text { Доза, } \\
\text { г (мл) / кг }\end{array}$ & $\begin{array}{c}\text { Сроки купирования } \\
\text { клинической } \\
\text { симптоматики, ч }\end{array}$ & Заболеваемость, \% & Падеж, \% \\
\hline \multirow{3}{*}{$\begin{array}{l}\text { 1-я группа } \\
\text { Сорбент из коры осины }\end{array}$} & 0,1 & 89 & 80 & 60 \\
\hline & 0,15 & 80 & 60 & 40 \\
\hline & 0,2 & 72 & 60 & 40 \\
\hline \multirow{3}{*}{$\begin{array}{l}\text { 2-я группа } \\
\text { Исходная кора осины фр. } \\
<0,5 \text { мм }\end{array}$} & 0,1 & 72 & 60 & 60 \\
\hline & 0,15 & 56 & 40 & 40 \\
\hline & 0,2 & 48 & 40 & 20 \\
\hline \multirow{3}{*}{$\begin{array}{l}\text { 3-я группа } \\
\text { Кора осины фр. <0,5 мм с } \\
\text { нанесенным АГ }\end{array}$} & 0,1 & 72 & 40 & 40 \\
\hline & 0,15 & 54 & 40 & 20 \\
\hline & 0,2 & 48 & 20 & 0 \\
\hline \multirow{3}{*}{$\begin{array}{l}\text { 4-я группа } \\
\text { F витаминный комплекс или } \\
\text { «осиновый жир» }\end{array}$} & 0,1 & 36 & 40 & 20 \\
\hline & 0,15 & 24 & 20 & 0 \\
\hline & 0,2 & 24 & 20 & 0 \\
\hline $\begin{array}{l}\text { 5-я группа } \\
\text { Контроль }\end{array}$ & & - & 100 & 100 \\
\hline
\end{tabular}


Наибольшую эффективность при использовании препаратов из коры осины для профилактики генерализованных кишечных инфекций показал F-витаминный комплекс, или «осиновый жир», в дозе 0.15 и 0.2 г/кг. В этих группах сохранность животных составила $100 \%$, заболеваемость не превышала 20 \%, а прекращение клинической симптоматики отмечали в течение первых суток с момента заболевания.

Хорошую профилактическую эффективность показала исходная кора осины с нанесенным АГ (группа 3) в дозах 0.15 и 0.2 г/кг и исходная кора осины (группа 2) в дозе 0.2 г/кг. При введении экспериментальным животным данных препаратов не наблюдалось гибели животных, заболеваемость не превышала 20 \%, а сроки купирования клинической симптоматики составляли 48 ч.

Средние профилактические свойства в дозировках 0.15 и 0.2 г/кг установлены у коры осины фракции 1-2 мм, проэкстрагированной гексаном и обработанной щелочью: количество заболевших животных составило $60 \%$, сохранность - $40 \%$, а сроки купирования симптомов заболевания - 72 ч.

\section{Заключение}

Изучены сорбционные и терапевтические свойства препаратов для профилактики и лечения эшерехиоза животных, полученных из коры осины. Установлено, что все препараты имеют хорошие сорбционные свойства в отношении желатина и метиленового синего. Лучшими сорбционными свойствами обладает образец, полученный путем экстракции коры осины гексаном и обработки щелочью.

Установлено, что все полученные препараты можно использовать для лечения и профилактики эшерихиоза животных.

Хорошими терапевтическими и профилактическими свойствами обладает исходная кора осины при введении дозы 0.15-0.2 г/кг и кора осины с нанесенным арабиногалактаном при оптимальной дозе 0.15 г/кг. Средняя терапевтическая эффективность установлена для препарата из проэкстрагированной гексаном коры осины при введении препарата в дозе 0.15-0.2 г/кг.

Наиболее высокой эффективностью в лечении и профилактике острого экспериментального эшерихиоза у мышей отличается препарат на основе «осинового жира», полученного экстракцией коры гексана при оптимальных дозах 0,1-0,15 мл/кг.

С учетом себестоимости получения этих препаратов можно сделать вывод о целесообразности использования для лечения желудочно-кишечных инфекций животных измельченной исходной коры осины в дозе 0.15 г/кг, а для профилактики - коры осины с нанесенным арабиногалактаном в дозе 0.15 г/кг.

Так как генерализованная кишечная инфекция на биологических моделях проводилась с применением вирулентных штаммов кишечной палочки, выделенной на промышленном поголовье свиней, то полученные препараты из коры осины можно рекомендовать для практического применения на свинокомплексах и птицефабриках региона.

Выражаем благодарность сотрудникам центра коллективного пользования ИХХТ СО РАН, ФИЦ КНЦ СО РАН Е.В. Мазуровой и И.В. Корольковой за проведение физикохимических исследований. 
Исследование выполнено в рамках базового проекта № 0356-2016-0505 (V.46.4.2.) Программы фундаментальных научных исследований государственных академий наук на 2013202022.

\section{Список литературы}

1. Кузнецов Б.Н., Левданский В.А., Кузнецова С.А. Химические продукты из древесной коры. Красноярск: СФУ, 2012. 259 с. [Kuznetsov B.N., Levdansky V.A., Kuznetsova S.A. Chemical products from wood bark. Krasnoyarsk: Siberian Federal University, 2012. 259 p. (In Russ.)]

2. Дейнеко И.П., Фаустова Н.М. Элементный и групповой химический состав коры и древесины осины. Химия растительного сырья 2015. № 1, С. 51-62. [Deineko I.P., Faustova N.M. Elemental and group chemical composition of bark and aspen wood. Chemistry of Plant Raw Materials 2015. No. 1, P. 51-62. (In Russ.)]

3. Долгодворова С.Я., Бурлакова Р.Ф., Перышкина Г.И., Черняева Г.Н. Содержание липидов в древесине и коре осины. Химия древесины 1988. № 4, С. 95-98. [Dolgodvorova S.Ya., Burlakova R.F., Peryshkina G.I., Chernyaeva G.N. The content of lipids in wood and aspen bark . Wood Chemistry 1988. No. 4, P. 95-98. (In Russ.)]

4. Vanek V.W., Allen P., Harvey Banchik L.P., Bistrian B. and others. Parenteral nutrition intravenous fat emulsions product shortage considerations. Nutr Clin Pract. 2013 .Vol. 28 (4), P. 528-529.

5. Ronald K. Tew Seasonal Variation in the Nutrient Content of Aspen Foliage. The Journal of Wildlife Management 1970. Vol. 34(2), Р. 475 - 478.

6. Сафин Р.Г., Зиатдинова Д.Ф., Арсланова Г.Р. Экстрагирование биологически активных веществ из коры осины. Лесной вестник 2017. T. 21(2), C. 65-69. [Safin R.G., Ziatdinova D.F., Arslanova G.R. Extraction of biologically active substances from aspen bark. Forestry Bulletin 2017. Vol. 21(2), P. 65-69. (In Russ.)]

7. Алексеева Е.А., Пильняк В.Н., Агранат А.Л., Солодкий Ф.Т. Состав жирных кислот липидов коры осины. Изв. высш. учебн. заведений. Лесной журнал 1970. № 6, С. 96-99. [Alekseeva E.A., Pilnyak V.N., Agranat A.L., Solodky F.T. Composition of fatty acids of lipids of aspen bark. Izv. higher studies institutions. Forest Journal 1970. No. 6, Р. 96-99. (In Russ.)]

8. Фаустова Н.М. Химический состав коры и древесины осины. Дис. канд. хим. наук. Санкт-Петербург: Гос. лесотехн. академия, 2005. 208 c. [Faustova N.M. The chemical composition of the bark and wood of aspen. Dissert Candidate of Chemical Sciences. St. Petersburg: State forest technology Academy, 2005. 208. (In Russ.)].

9. Kulov R. Health effects of gamma liniletic acid, conjugated linoleic acid and herbal preparations. Can. Chem. News 1997. Vol. 49(10), P. 12-16.

10. Desbois A.P., Smith V.J. Antibacterial free fatty acids: activities, mechanisms of action and biotechnological potential. Applied Microbiology and Biotechnology 2010. Vol. 85(6), P. 1629-1642.

11. Крылова С.Г., Зуева Е.П., Разина Т.Г., Турецкова В.Ф., Амосова Е.Н. Сухой экстракт осины в экспериментальной терапии язвенной болезни желудка. Экспериментальная и клиническая фармакология 2000. T. 63(2), C. 44-47. [Krylova S.G., Zueva E.P., Razina T.G., Turetskova V.F., Amosova E.N. Dry aspen extract in experimental therapy of gastric ulcer. Experimental and clinical pharmacology 2000. Vol.63(2), P. 44-47 (In Russ.)] 
12. Krylova S.G., Turetskova V.F., Makarova O.G. Technology Development and Antiulcer Activity of Gastroretentive Tablets with Aspen Bark Dry Extract. Pharmaceutical Chemistry Journal 2018. Vol. 52(2), P. 133-138.

13. Кузнецов Б.Н., Левданский В.А., Кедрова Л.К. и др. Выделение и изучение экстрактивных веществ из коры древесины осины. Химия растительного сырья 1998. № 3, С. 5-12. [Kuznetsov B.N., Levdansky V.A., Kedrova L.K. et al. Isolation and study of extractive substances from the bark of aspen wood. Chemistry of plant raw materials 1998. № 3, P. 5-12 (In Russ.)]

14. Карпунь И.М., Бабина М.П. Профилактика иммунных дефицитов и желудочнокишечных болезней у цыплят-бройлеров. Ветеринария сельскохозяйственных животных 2005. № 6, C. 16-17. [Karpun I.M., Babina M.P. Prevention of immune deficiencies and gastrointestinal diseases in broiler chickens. Veterinary farm animals 2005. No. 6, P. 16-17. (In Russ.)]

15. Веприкова Е.В., Щипко М.Л., Кузнецова С.А., Кузнецов Б.Н. Получение энтеросорбентов из отходов окорки березы. Химия растительного сырья 2005. № 1, С. 65-70. [Veprikova E.V., Shchipko M.L., Kuznetsova S.A., Kuznetsov B.N. Receiving enterosorbents from waste birch debarking. Chemistry of plant materials 2005. No. 1, P. 65-70. (In Russ.)]

16. Патент 2611388 РФ. Кузнецова С.А., Кузнецов Б.Н., Мороз А.А., Скворцова Г.П., Счисленко С.А., Чесноков Н.В. Энтеросорбент из луба березовой коры. Опубл. 21.02.2017 [Patent 2611388 RU. Kuznetsova S.A., Kuznetsov B.N., Moroz A.A., Skvortsova G.P. Enterosorbent from the bast of birch bark. Publ. Date 02.21.2017. (In Russ.)]

17. Патент 2389498 РФ. Кузнецова С.А., Кузнецов Б.Н., Ковальчук Н.М., Скворцова Г.П. Энтеросорбент. Опубл. 20.05.2010. [Patent 2389498 RU. Kuznetsova S.A., Kuznetsov B.N., Kovalchuk N.M., Skvortsova G.P. Enterosorbent. Publ. Date 05.20.2010 (In Russ.)]

18. Веприкова Е.В., Кузнецова С.А., Королькова И.В., Мороз А.А., Счисленко С.А., Кузнецов Б.Н., Чесноков Н.В. Изучение сорбционных и лечебно-профилактических свойств энтеросорбента из коры лиственницы. Химия растительного сырья 2018. № 1, С. 201-209. [Veprikova E.V., Kuznetsova S.A., Korolkova I.V., Moroz A.A., Schislenko S.A., Kuznetsov B.N., Chesnokov N.V. The study of the sorption and therapeutic properties of enterosorbent from larch bark. Chemistry of plant materials 2018. No. 1, P. 201-209. (In Russ.)]

19. Решетников В.И. Оценка адсорбционной способности энтеросорбентов и их лекарственных форм. Химико-фармацевтический журнал 2003. Т. 37(5), С. 28-32. [Reshetnikov V.I. Evaluation of the adsorption capacity of enterosorbents and their dosage forms. Chemical Pharmaceutical Journal 2003. Vol. 37(5), P. 28 - 32. (In Russ)]

20. Markelov D.A., Nitsak O.V., Gerashenko T.T. Comparative study of the adsorption activity of medicinal sorbents. Pharmaceutical Chemistry Journal 2008. Vol. 42(7), P. 405 - 408.

21. МУ 13-7-2/2117. Бактериологическая диагностика колибактериоза (эшерихиоза) животных. Москва. Утв. МСХиП РФ. 2000. [Bacteriological diagnosis of colibacteriosis (colibacillosis) of animals. Moscow. Ministry of Agriculture and Social Sciences. MU 13-7-2 / 2117. 2000 (In Russ.)]

22. МУ13-7-2/1759 Бактериологическая диагностика смешанной кишечной инфекции молодняка животных, вызываемой патогенными энтеробактериями. Москва. МСХиП РФ, 1999. [MU13-7-2 / 1759 Bacteriological diagnosis of mixed intestinal infection of young animals caused by pathogenic enterobacteria. Ministry of Agriculture of the Russian Federation, 1999. (In Russ.)] 